\title{
Board Independence and Credit Ratings
}

Article in SSRN Electronic Journal · January 2010

DOI: $10.2139 /$ ssrn. 1572158

CITATIONS

0

2 authors, including:

Dong Chen

University of Baltimore

17 PUBLICATIONS 80 CITATIONS

SEE PROFILE
READS

40

All content following this page was uploaded by Dong Chen on 06 November 2015.

The user has requested enhancement of the downloaded file. All in-text references underlined in blue are added to the original document and are linked to publications on ResearchGate, letting you access and read them immediately. 


\title{
Board Independence and Credit Ratings
}

\author{
Michael Bradley ${ }^{1}$ and ${\underline{\text { Dong } \text { Chen }^{2}}}^{2}$
}

\begin{abstract}
Using Sarbanes-Oxley Act (SOX) as a natural experiment, we find evidence consistent with an optimal level of board independence for credit ratings. We test two hypotheses that could explain this optimality: information cost hypothesis (ICH) that the effectiveness of independent boards increases with the private benefits of the management, and decreases with the cost of monitoring and advising, and the shareholder empowering hypothesis (SEH) that the empowering of shareholders through stronger board independence reduces the agency cost of equity but exacerbates the agency cost of debt. We find mixed evidence supporting ICH, and stronger evidence supporting SEH.
\end{abstract}

September 2009

Keywords: board independence, credit rating, corporate governance, agency cost of debt, monitoring, advising, information cost, shareholder empowering

\footnotetext{
${ }^{1}$ Duke University, 1 Towerview Dr. Durham, NC, 27708. bradley@duke.edu, (919)660-8006

${ }^{2}$ University of Baltimore, 1420 N Charles St, Baltimore, MD 21201. dchen@ubalt.edu, (410)837-4919
} 
There is limited research for the relation between corporate governance and credit ratings. This is puzzling for two reasons. On the one hand, credit rating is very important in practice based on Graham and Harvey (2001)'s survey: managers consider it as the second most important factor in making debt policies. A higher rating often implies a lower cost of borrowing, and ceteris paribus, a higher firm value. ${ }^{3}$ On the other hand, credit rating agencies (e.g. Fitch Ratings (2004), and Dallas and Kochetygova (2007)) consider corporate governance as a separate risk factor in their ratings assessment, aside from the financial characteristics.

Economists' reluctance to study the determinants of credit ratings is understandable: after all, ratings are assigned by rating agencies. A more straightforward and possibly better way to study ratings is to simply ask the rating agencies for their secret formula. Yet as Ashbaugh-Skaife, Collins, and LaFond (2006, ACL henceforth) and Bradley, Chen, Dallas, and Snyderwine (2008) point out, rating agencies do not use a formulaic approach to assign the ratings. Ratings are assigned by the committees. Thus, a study of the relation between credit ratings and corporate governance, and to put this study in the context of financial theories is not a redundant exercise. In light of the debate on the effectiveness of rating agencies in assigning the ratings during the current financial crisis, this study should be of particular value.

This paper is one step in filling the gap in this line of research. We study the relation between credit ratings and one of the most prominent corporate governance mechanisms: board

\footnotetext{
${ }^{3}$ A recent example of how credit ratings can influence stock price is General Electric. The company's rating is downgraded one notch by both Moody's and Standard \& Poor from AAA to AA+. The share price dropped precipitously upon the rumor for the downgrade.
} 
independence. ${ }^{4}$ Our proxy for board independence follows most other empirical paper on corporate boards (Hermalin and Weisbach (2003)), the percentage of independent directors to total board size. We ask two closely related questions. First, what is the relation between credit ratings and board independence? Second, what financial theory could explain this relation? We use the passage of Sarbanes-Oxley Act (SOX) in 2002 and the associated change of major exchange listing standards on corporate governance as a natural experiment, and the differencein-difference method to tackle the endogeneity problem that plagues the corporate governance studies (Hermalin and Weisbach (2003), and Adams, Hermalin and Weisbach (2008)). SOX imposed a higher independence standard by requiring all the public companies to have fully independent audit committees. Major exchanges, such as NYSE, NASDAQ, and American Exchange (AMEX) further require the majority of the directors to be independent and fully independent compensation and nomination committees. ${ }^{5}$

Our major findings are summarized below. We find the ratings of the firms with less than majority independent boards in 2002 (non-compliant firms henceforth), the year when SOX was passed, are on average upgraded more than firms which complied with SOX in 2002, even after controlling for the effect of committee compliance and other financial characteristics that may

\footnotetext{
${ }^{4}$ In S\&P's corporate governance framework in its evaluation of firms' credit ratings, board structure and process is one of the four categories of governance mechanisms. The other three are ownership structure and influence, financial transparency, and financial stakeholder rights and relations. See Standard and Poor (2002).

${ }^{5}$ NYSE imposes the strictest standard among the three. It requires its listed firms to have the three major committees with all independent directors, as well as majority independent full boards. NASDAQ and AMEX require the firms to have more than majority independent boards and a fully independent audit committee. But it stops short of requiring each firm to have the compensation and nomination committees. If the firms do have these committees, the two exchanges require them to be fully independent. But one can argue that the climate surrounding the passage of SOX and new governance listing standards for major exchanges is sufficient to push firms to voluntarily adopt the stricter standards by having all three major committees and be fully independent. Our evidence supports this argument.
} 
affect ratings. This result suggests that rating agencies value independent boards positively in assigning the ratings, consistent with the findings in Bhojraj and Sengupta (2003, BS henceforth) and ACL. However, when we further separate the non-compliant firms into two groups based on their independence, we find the positive effect of the increase of board independence on credit ratings is only significant for the low-independent group, even when its increase of the board independence is not significantly different from the other higher independent but non-compliant group. This result is consistent with the idea that there might be an optimal level of board independence above which rating agencies no longer value independence positively, or even value it negatively. In our specification of the model, we find that this optimal level of board independence is around 0.54 for the average firm in the sample, which is very close to the majority requirement that the exchanges imposed on the public companies. ${ }^{6}$

We then test the theories that may explain this optimality of board independence, i.e., what costs are there to have independent directors. We consider two major non-exclusive hypotheses: the information cost hypothesis $(\mathrm{ICH})$ that the effectiveness of independent boards increases with the private benefits of the management but decreases with the cost of monitoring and advising (Raheja (2005), Adams and Ferreira (2007), and Harris and Raviv (2006)), and the shareholder empowering hypothesis (SEH) that the empowering of shareholders through stronger board independence reduces the agency cost of equity but exacerbates the agency cost of debt (Fama and Miller (1972)).

\footnotetext{
${ }^{6}$ This does not imply a uniform optimal board independence level, as firms may differ for this optimal level given different contracting environment. Our two hypotheses: ICH and SEH is predicated on this difference.
} 
Though Raheja (2005), Adams and Ferreira (2007), and Harris and Raviv (2006))'s models are all based on equity holders, they can be extended to include bondholders straightforwardly, as both are stakeholders of the firm and they have the mutual interest in containing the agency cost from the management. In $\mathrm{ICH}$, board's monitoring reduces the private benefits of management and is more effective when such benefit increases. However, board's monitoring and advising requires the firm-specific information that is costly to acquire by independent directors. These two opposing effects may imply an interior solution to the board composition when maximizing the firm value. We use several proxies for the information cost as in Boone, Field, Karpoff, and Raheja (2007) and Linck, Netter, and Yang (2008). We use R\&D expenses, market-to-book ratio, and stock return volatility as the proxies for the information cost. We find mixed evidence supporting the ICH. Consistent with the hypothesis, adding independent directors through SOX and exchange regulations increase ratings for firms with low R\&D expenses, and firms with low market-to-book ratios, it also increases the ratings for firms with high equity volatility, which is inconsistent with the hypothesis.

In $\mathrm{SEH}$, both shareholders and bondholders are benefited through a more independent board when the independence is not too high, as the agency cost from the management is reduced through the board's monitoring. But as independence further increases, director's fiduciary duty for shareholders may imply stronger shareholders' power relative to bondholders'. And the conflict between these two stakeholders may be exacerbated through the incentives for risk shifting (Jensen and Meckling (1976)) and debt overhang (Myers (1977)), especially when the firm is closer to default and the director hold more shares (hence more aligned with 
shareholders). Thus, independent directors' monitoring coupled with their empowering of the shareholders implies an optimal level of independence. To test SEH, we test the differential effect of the increase of independence on firms' credit ratings, conditional on whether the firm is investment-grade or speculative-grade, and conditional on whether the shareholdings of the directors are above or below the median in the sample. The evidence supports SEH, the beneficial effect of independence on credit ratings is only significant for investment-grade firms when presumably the conflict between shareholders and bondholders is not strong, and for firms whose average director shareholding is below the sample median. Furthermore, when we interact the speculative-grade dummy with the dummy for director shareholdings, we find among the speculative-grade firms, the insignificant effect of independence on credit ratings is only present for firms whose directors hold more shares. For firms whose directors hold less shares, the increase of the independence continues to be positive and significant for credit ratings. The result is consistent with the idea that independence benefits bondholders when the conflict between shareholders and bondholders is not strong, such as when the firm is investment-grade, or the independent directors' interests are not too aligned with the shareholders' through explicit incentive shareholdings, and this effect is captured by rating agencies' credit ratings.

This paper makes several contributions to the existing literature and the policy debate on corporate governance. First, we add to the small strand of research that studies the effect of corporate governance from the bondholders and rating agencies' perspective (BS, ACL, Anderson, Mansi, and Reeb (2004), Klock, Mansi, and Maxwell (2005), Cremers, Nair, and Wei (2007), Chava, Dierker, Livdan, and Pumanandam (2008), Qiu and Yu (2008)). Most papers use 
bond yield or spread as the proxy for the cost of debt (as cited above, except for BS and ACL, all other papers use bond spread as the proxy for the cost of debt). Fewer papers use credit ratings (BS, ACL). As Bradley, Chen, Dallas, and Snyderwine (2009) point out and their evidence demonstrate, it is not to be assumed that governance matters the same for bond spreads as for credit ratings, as bond traders on the market may have divergent opinion for the effect of governance from the rating agencies. From the firms' perspective, credit ratings are more relevant for new financings, as it directly affects their borrowing cost. Hence, following BS and ACL, we add to the small literature that studies the effect of corporate governance from the rating agencies' perspective. But unlike BS and ACL, who use cross-sectional approach for the study, and hence suffer from severe endogeniety concern and appropriate interpretation of their results (Adams, Hermalin and Weisbach (2008)), we use an exogenous shock brought about by the corporate scandals, the passage of SOX and the associated change of exchange listing standards, and the difference-in-difference approach coupled with panel fixed-effect model to tackle the omitted correlated variable and endogeneity problem. Also unlike BS and ACL, who find independence matters positively for credit ratings, we find there might be an optimal level of independence above which the positive effect of independence no longer holds. ${ }^{7}$

Second, our work also adds to the burgeoning literature on the effectiveness of board independence in performing its major functions: monitoring and advising. Recent theories on the

\footnotetext{
${ }^{7}$ We test the robustness of the results in BS and ACL by following their specifications. We are able to confirm their findings. However, when we add more industry controls and equity volatility variable in their specifications, the significant effect of board independence disappears. Thus, their claim that board independence is viewed positively by rating agencies should be taken with caution, though both their papers and ours find positive effect of board independence on credit ratings (ours have the condition that independence should not be too high).
} 
board model the board as an endogenous institution by incorporating the benefit of reducing management' private benefits, and the cost for the monitoring and advising (Raheja (2005), Adams and Ferreira (2007), Harris and Raviv (2006). Thus, an independent board might be effective for some firms but not for others. Empirical evidence finds mixed support for the theories (Boone et al. (2007), and Linck, Netter, and Yang (2008)). These models and empirical tests, however, are all based on the shareholder-management agency conflict. To our knowledge, this is the first paper that tests the effectiveness of an independent board derived from the latest board theories and from the rating agencies' perspective. Like Boone et al. (2007) and Linck, Netter, and Yang (2008), our results provide mixed support for the theories. In our setting, we are also able to test the effectiveness of independent board in light of the conflict between stockholders and bondholders, and to what extent this conflict is captured by the rating agencies. Our results provide evidence supporting this conflict argument. To our knowledge, this is also the first paper that tests the agency cost of debt in the context of ratings, and find supportive evidence.

Third, this paper adds to the ongoing debate about the puzzling result that board independence matters and is generally effective for specific tasks such as CEO turnover, CEO compensation, and to adopt anti-takeover device (such as poison pill), but is generally not associated with firm performance (Hermalin and Weisbach (2003), Chhaochharia and Grinstein (2009), Duchin, Matsusaka and Ozbas (2009)). A sensible explanation for this apparent inconsistency is that board structure is endogenously chosen to balance the benefit and cost of more independent boards. In equilibrium, therefore, we should not expect a significant relation between board 
independence and firm performance (Demsetz and Lehn (1985)). While prior literature (e.g., Duchin, Matsusaka and Ozbas (2009) has focused on the information cost of board's monitoring and advising, as our ICH in this paper, we propose another explanation based on the results confirming our SEH. Since board independence may benefit shareholders at the expense of bondholders as captured by the rating agencies' assessment of firms' credit ratings, ${ }^{8}$ and ultimately the higher borrowing cost is absorbed by shareholders in terms of lower firm value, it may be optimal for shareholders to limit the independence of the board and the explicit director shareholdings to reduce the agency cost of debt. Thus, the conflict between the two stakeholders implies an interior solution for board's independence, and an insignificant relation between such independence and firm value if the model is correctly specified.

Fourth, this paper also sheds light in the evaluation of the benefit and cost of SOX on security holders. Most prior literature study SOX from the shareholders' perspective, and find mixed evidence that SOX benefits shareholders (Chhaochharia and Grinstein (2007), Zhang (2007), and Wintoki (2007)). DeFond, Hung, Karaoglu, and Zhang (2008), Andrade, Bernile, and Hood (2008) and Bradley and Chen (2009) study the effect of SOX from the bondholders' perspective by using bond spread as the proxy. While DeFond, Hung, Karaoglu, and Zhang (2008) and Bradley and Chen (2009) find that SOX leads to the increase of the cost of debt, Andrade, Bernile, and Hood (2008) find the opposite. To our best knowledge, ours is the first to study the effect of SOX on firms' credit ratings. Our "optimality" evidence is in contrast with that of DeFond, Hung, Karaoglu, and Zhang (2008) and Bradley and Chen (2009), and provides a

\footnotetext{
${ }^{8}$ See Ashbaugh-Skaife, Collins, and LaFond (2007) for the evidence that board independence is associated with lower cost of equity.
} 
further case that the result with respect to bond spread should not be taken granted for credit ratings, as bond traders and rating agencies may value governance provisions differently (Bradley, Chen, Dallas, Snyderwine (2009)). Our evidence suggests some benefit as well as cost of SOX from the rating agencies' perspective. While the majority independence requirement may benefit firms in reducing credit risk, other provisions such as independent audit committee and compensation committee, and especially the climate that pushed many firms' board structure well beyond the majority independence (as our evidence shows), may not be optimal to reduce the borrowing cost of the firm.

Finally, our work may also contribute to the debate on the effectiveness of rating agencies in assigning ratings that may have exacerbated the financial crisis started in 2007, and the possible new regulation that may affect this industry dramatically. ${ }^{9}$ The rating agencies have often been blamed for giving more optimistic ratings to some firms, especially the structured investment vehicles (SIV), than the underlying credit risk warranted. While certainly not conclusive, our evidence suggests that credit rating agencies may assign the ratings with prudence and sophistication. Our results imply that regulations should probably target the problematic area of the ratings, such as SIVs. More research are needed in the evaluation of the effectiveness of rating agencies to make any conclusions, however. ${ }^{10}$

The rest of the paper is organized as follows. In Section I we develop the two major hypotheses and review the major component of SOX that are relevant for our study. Section II

\footnotetext{
${ }^{9}$ Scannel (2009) reports that SEC passed rules which reduced the demand for the three major agencies' rating service (Moody's, S\&P, and Fitch Ratings). More regulations are expected to dramatically reshape the industry.

${ }^{10}$ It is interesting to note that the rating agencies have been changing their standards to rate CDOs, a special type of SIVs. See Miller (2009).
} 
describes the data, rating and independence variables, and the empirical methodology we use for the regression analysis. Section III reports the results. In Section IV we describe several robustness tests that corroborate our major findings. Finally, Section V concludes.

\section{Hypothesis Development and New Regulations}

Prior literature on credit ratings focus on financial ratios that may explain the observed ratings (Horrigan (1966) and Kaplan and Urwitz (1979)). As many rating agencies acknowledge, corporate governance is also a risk factor that may affect firms' probability to default (Fitch Ratings (2004), Standard \& Poor (2002)). Without proper monitoring through the governance

mechanisms, management may pursue self-interest at the expense of stakeholders, including shareholders and bondholders. Stakeholders may also have conflict of interest in getting a bigger size of the pie, especially when the firm's performance deteriorates (e.g., the asset substitution and debt overhang as in Jensen and Meckling (1976) and Myers (1977)). Hence, governance that affects the balance of power between management and stakeholders, and between various types of stakeholders, should affect the probability that debt holders get their promised interest and principal payment, hence firm's credit ratings.

Independent directors, due to their less allegiance to management, are supposed to play a more effective monitoring role. In addition, as many of the independent directors are executives or retired executives themselves from other firms, they bring valuable business expertise to the firms for which they serve as directors. These two roles, monitoring and advising, imply that the 
increase of board independence can reduce the credit risk. In a frictionless world, this positive effect further implies that every firm should have fully independent board.

But the two roles, monitoring and advising by independent directors are costly. To play these roles effectively, independent directors need accurate and detailed firm-specific information, which in many cases is hard to obtain, especially for the firms whose assets are mostly in the form of growth opportunities, such as firms with high R\&D expenses. Recent models on corporate boards realize these costs and derived the optimal level of independence, and the higher the information cost, the lower such level (Raheja (2005), Adams and Ferreira (2007), and Harris and Raviv (2006)). Empirical evidence gives mixed support for these models (Boone et al. (2007) and Linck, Netter, and Yang (2008)). As noted in the introduction, these models assume that independent directors serve the best interest of shareholders as many state laws require them so, but debt holders also benefit from the reduced agency cost of equity and independent directors' business expertise. Hence it is a straightforward extension of their models to derive the hypothesis that the dependence on the firm-specific information to monitor and advise effectively drives the optimality of independence, namely, it is generally the case that less than fully independent board is optimal for the firm. We name this hypothesis the information cost hypothesis or ICH.

Hypothesis 1 (Information Cost Hypothesis, ICH): The optimal level of board independence is derived by balancing the benefit of reducing the private benefits of management, and the cost of acquiring firm-specific information in independent directors' monitoring and advising functions. 
The increase of independence may also bring an "implicit" cost to bondholders. As corporate board owes its fiduciary duty to the shareholders, an increase of independence suggests a stronger voice representing shareholders' interest, and a weaker voice upholding bondholders'. In light of the conflict between these two stakeholders due to their different risk preference (Jensen and Merkling (1976) and Myers (1977)), a more independent board may imply higher default risk for bondholders, hence lower credit ratings. This bondholder weakening effect will be stronger when the firm is closer to default, as the size of the pie becomes smaller, and when independent directors are more closely aligned with shareholders, such as through shareholdings. The reduction of the default risk due to independent directors' monitoring and advising functions, and the increase of the risk due to stronger shareholders and their risk shifting incentives, may imply an optimal level of board independence. We term this hypothesis the shareholder empowering hypothesis or SEH.

Hypothesis 2 (Shareholder Empowering Hypothesis, or SEH): The optimal level of board independence is derived by balancing the benefit of reducing the private benefits of management through independent directors' monitoring and advising functions, and their risk-shifting incentives who owe fiduciary duties to shareholders or hold shares.

As argued in Adams, Hermalin, and Weisbach (2008), the study on corporate board is inherently suffering from the endogeneity problem, as board structure is chosen as one governance mechanism given firms' contracting environment. Though major rating agencies may consider board structure in assessing firms' default risk, the causality could as well run the other direction: simply because credit rating is such an important factor for corporate policies 
(Graham and Harvey (2001), board structure might quite plausibly respond to the change of credit ratings. This also might generate an association between board structure and credit ratings, but it has nothing to do with board affecting the credit risk. This suggests that any study that uses cross-sectional regressions may encounter the problem of correct interpretation of their results (BS, ACL).

In this paper we use the passage of SOX and the associated change of exchange regulations as an exogenous shock to tackle the endogeneity concern. SOX was passed in response to a series of high-profiled corporate scandals: Enron, Worldcom, Global Crossing, etc., and is designed to tighten the standards of corporate watchdogs: auditors, board of directors, internal control and financial disclosure, and security analysts. SOX imposes a higher standard on board independence, it requires all the publicly listed firms to have fully independent audit committees. The climate associated with the corporate failures and the passage of SOX also pushes major exchanges to pass new listing standard for corporate governance. The three major exchanges, NYSE, NASDAQ, and AMEX all require their listed firms to have at least majority independent boards. Furthermore, in addition to the SOX provision that every public firm have an audit committee and be fully independent, NYSE further requires all its listed firms to have the compensation and nomination committees, and be fully independent. NASDAQ and AMEX do not force the firms to have the two committees, but require them to be fully independent if the firms choose to have them. All these new regulations will supposingly increase the independence of the board. Furthermore, the climate associated with the corporate failures may also push firms 
to voluntarily adopt higher independence than the regulations impose to be certified as the "good guys", as our evidence suggests.

The major exchanges required firms to adopt these changes during their first annual meeting after January 15, 2004, but no later than October 31, 2004. Firms with classified board structure, that generally only one-third of the directors are up for election every year, were given until the second annual meeting to comply, but no later than December 31, 2005.

\section{Data, Variables, and Methodology}

\section{A. Data and Sample}

Our sample is derived from two major data sources: RiskMetrics (formerly IRRC) director database, and CRSP-COMPUSTAT merged database. The RiskMetrics database covers firms in the S\&P 1500 index from 1996 to 2005. It lists the director profiles such as independence, committee membership, and shareholdings. The credit rating and financial characteristics are from the CRSP-COMPUSTAT database. After merging these two databases, we are left with 5883 firm-year observations with non-missing data from 1996 to 2005.

\section{B. Variables and Summary Statistics}

\section{B.1 Board Independence}

The board independence is calculated from dividing the number of independent directors to total board size. RiskMetrics' independence standard is higher than the major exchanges'. NYSE restricted independent directors to be non-employees, to have no prior employment with the firm or at least three years after their termination of the employment, and to have no substantial 
business transactions with the firm. RiskMetrics went further by restricting independent directors to have no prior employment and have no business transaction with the firm at all. As our purpose is to study the effect of imposed SOX and exchange listing standard on credit ratings, we follow Chhaochharia and Grinstein (2009) to partially adjust for the RiskMetrics data by redefining the director as independent if his/her employment with the firm has terminated for at least three years. We are unable to adjust for the independence based on the business transaction as RiskMetrics does not have the volume data for this item. As Chhaochharia and Grinstein (2009) point out, this potential measurement error may bias our analysis against finding a significant relation between independence and credit ratings, as firms who are classified as noncompliant in 2005 by RiskMetrics might as well be compliant by the exchanges.

Figure 1 plots the mean and the median of the board independence over the sample period. A clear uptrend is obvious from the figure. This suggests that even before the enactment of SOX in 2002, the average firm in the sample has been increasing its independence. In addition, the independence for the mean and median firm in the sample was over majority even at the start of the sample year 1996. Several reasons might have contributed to this upward trend before SOX: First, the requirement by NYSE in 1999 for its listed to have independent audit committees; second, the institutional activism that demands a higher board independence and accountability with the growth of institutional investors, especially pension funds such as TIAA-CREFF and CALPERS. However, it can also be seen from the figure that between 2002 and 2003 there is a jump of the independence for the average firm in the sample, and independence further increases significant between 2003 and 2005. 
This pattern of independence can also be seen from Panel A of Table 1. To save space, the table only lists the compliance trend between 2000 and 2005. Though board independence and committee independence increased between 2000 and 2002, the biggest increase is between 2003 and 2005, suggesting that SOX and the new exchange regulations have a significant effect on boards' independence. The upward trend of independence, coupled its apparent jump between 2002 and 2003, makes it necessary to control for the time effects in the regressions, and appropriate to separate the sample into pre-2002 period and post-2002 period. We use differencein-difference with a cutoff treatment year to be 2002, which is consistent with the pattern we observed in Figure 1 and Table 1. But we also check for other cutoff years and find similar results.

Panel A also lists the summary statistics of board independence and size. Consistent with the pattern observed in Linck, Netter, and Yang (2009), the mean board size decreased before SOX then increased after SOX, probably due to more workload imposed on directors hence higher demand for more directors. But compared with the change of average independence from 0.65 to 0.73 (median from 0.67 to 0.75 ), the change of board size is small. The median board size kept constant at 9 members across the period.

Panel A also lists the proportion of NYSE-listed firms in each year, which has the strictest compliance standard. Supermajority of the firms are NYSE-listed, which suggests it is appropriate to use the committee independence as another exogenous shock. The evidence in Panel A also suggests that many non-NYSE listed firms may voluntarily choose to have an independent compensation and nomination committee, as in 2005 the proportion of NYSE firms 
is 0.72 but the proportion of non-independent nomination committee is only 0.23 , which includes those firms without a nomination committee.

\section{B.2 Credit Ratings}

Credit Rating is obtained from COMPUSTAT data280, the S\&P long-term domestic issuer credit rating. The S\&P credit rating has 22 major categories, from D (debt in default) to AAA (extremely strong capacity to pay interest and repay principal). COMPUSTAT code data280 as the higher the credit rating, the lower the value. We convert data280 to our credit rating variable as in Table 2. After the conversion, the higher the credit rating, the higher is its numerical value. The business community often term the ratings below BBB- as speculative-grade or "junk" bonds, and rating above to be investment-grade bonds. In our numerical coding, a credit rating below 13 is coded as speculative-grade, and at or above 13 as investment-grade.

Figure 2 plots the time trend of credit ratings over the sample period. In contrast with the upward trend of board independence, the average credit rating generally experienced a downward trend, consistent with many other findings (e.g., Blume, Lim, and Mackinlay (1998)). But the downward trend was reversed after 2004, when the mean rating began to increase. In Panel B of Table 1 we present the summary statistics of credit ratings. The COMPUSTAT database has a significant number of missing data for data280. As can be seen from the panel, the number of non-missing data for credit ratings in 2002 is 710 , only $58 \%$ of the number of nonmissing data for independence in 2002 (1205). This will give rise to only 69 non-compliant firms in 2002 for non-missing credit rating data. To potentially enlarge the sample of non-compliant 
firms to increase the power of the statistical tests, we use an unbalanced panel between 1996 and 2006, instead of a balanced panel, as commonly done for difference-in-difference studies. To make sure that firms will appear at least once both before 2002 and after 2002, we use the nonmissing sample for independence at 2002 as our baseline group, and merge this group with the rest of the sample years to ensure that no firm is not part of this group in 2002. This necessitates that we have the largest number of firms in 2002 for non-missing independence data, as Panel A shows. As it turns out, the year 2002 also has the largest number of non-missing credit rating data. This suggests that some firms may consistently have the missing data280 in COMPUSTAT database across the sample years. Though this unbalanced sample is our primary regression sample, we check the robustness of the results by replying on balanced panel between 2000 and 2005 for all non-missing credit rating data. The results are statistically weaker but qualitatively the same.

\section{B.3 Control Variables}

Control variables are based on a survey of prior literature (Horrigan (1966), Kaplan and Urwitz (1979), ACL, and Bradley, Chen, Dallas, and Snyderwine (2009)). We control for firm size (Size) as proxied by the natural log of total assets (data6 in COMPUSTAT), leverage ratio (Lev) as proxied by the debt in current liabilities (data34) plus long-term debt (data9) divided by the total assets, return on assets (ROA) as proxied by income before extraordinary items (data18) divided by total assets, and the standard deviation of past 60 months' stock returns calculated from CRSP (Volat). The mean and median values of these control variables each year between 2000 and 2005 are listed in Panel C of Table 1. Compared with Chhaochharia and Grinstein 
(2009), who use the same director database as ours, the average firm size is bigger than theirs, probably because we have an unbalanced sample and hence more firms for each year. Leverage and ROA are comparable to what reported in ACL. It can also be seen that firm size increases over time, probably because the larger firm has less non-missing observations for the total asset, and leverage ratio dropped during 2000 and 2005.

\section{Empirical Methodology}

If board independence affects credit ratings, we should expect the change of credit ratings for the non-compliant firms before SOX exceeds that of the compliant firms. We use the following difference-in-difference fixed-effect specification for our regression analysis:

$$
\begin{aligned}
& \text { Rating }_{i t}=\beta_{1} * \text { Dummy }\left(\text { per_ind }<0.5{ }^{\prime} 02\right)_{i} * \text { Post SOX }+\beta_{2} \\
& \left.* \text { Dummy (ind_audit }=0 \text { '02 })_{i} * \text { Post SOX }+\beta_{3} * \text { Dummy (ind_comp }=0 \text { '02 }\right)_{i} \\
& \left.* \text { Post SOX }+\beta_{4} * \text { Dummy (ind_nom }=0 \text { '02) }\right)_{i} \\
& * \text { Post SOX }+ \text { Controls }{ }_{i t}+\beta_{0 i}+\varepsilon_{i t}
\end{aligned}
$$

In the above specification, Rating $_{i t}$ is firm i's rating at year t. $\beta_{1}$ is the change of credit ratings for the non-compliant firms at 2002 after SOX relative to that of the compliant firms, and is our major estimate of interest. $\beta_{2}, \beta_{3}$ and $\beta_{4}$ are the change of credit ratings for the firms whose audit (compensation, nomination) committees are not fully independent at 2002 relative to the firms whose audit (compensation, nomination) committees are independent. Dummy $(\text { per_ind }<0.5 \text { '02) })_{i}$ is a dummy variable which equals to 1 if the firm's independence is less than majority at 2002, and zero otherwise. Dummy(ind_audit $=0$ '02) 
(Dummy(ind_comp $=0$ '02) $)_{i}$, Dummy $\left.\left(\text { ind } \_n o m=0 ' 02\right)_{i}\right)$ is a dummy variable which equals to 1 if the firm's audit (compensation, nomination) committee is less than fully independent at 2002, and zero otherwise. Post SOX is a dummy that equals to one if the year is between 2003 and 2005, and zero otherwise. Control variables are as described in Section B.3. We follow Chhaochharia and Grinstein (2009) to interest each control variable with Post SOX dummy and Before SOX , a dummy variable that equals to one if the year is before 2003, and zero otherwise. This takes into consideration the possibility that rating agencies might change their rating criteria following the corporate scandals. We also control for any unobservable but fixed firm effect $\beta_{0 i}$ in all models to take into consideration that rating agencies might value other aspects of the firm which are not captured in the model. In all our regression models, standard errors are adjusted for heteroscedasticity. Following Petersen (2008), we also cluster standard errors at the firm level.

We recognize that a linear specification like (1) may not be appropriate for the categorical and ordered dependent variable such as ratings. Prior literature (such as BS, ACL, and Bradley, Chen, Dallas, and Snyderwine (2009)) have used ordered-logit (or probit) specifications. But we believe our choice of the linear specification may be the second best given the following reasons: first, as is well known, ordered-logit (or probit) model uses maximum-likelihood estimates and may not be consistent for fixed-effect models due to the "incidental parameter problem" (Neyman and Scott (1948)); second, even if we were not to use the fixed-effect specification, the interpretation of the estimates are not as straightforward as that of the linear model, especially for 
the interaction of dummy variables as in our model. Since such interaction term is our major concern in this paper, we deem it appropriate to use the linear specification instead of orderedlogit models.

Our strategy to test whether there is an optimal level of independence for credit ratings is to separate the non-compliant sample into two sub-samples, with the independence of one group below the median value of the independence of the non-compliant firms, and another group above it, and then compare their change of ratings post SOX relative to the compliant firms. If there is an optimal level of board independence for ratings, then firms with higher independence, even if they are still non-compliant by the listing standards of the exchanges, may not enjoy the same improvement or no improvement at all for their ratings. To that effect, we use the specification in (1), but for the two sub-samples of non-compliant firms, to test whether $\beta_{1}$ is positive and significant in both regressions. We recognize that the increase of independence might be different for these two groups of non-compliant firms, since they have different independence before SOX. We use the time span that exchanges allow the listed firms to comply to solve this issue. The exchanges have given the firms until December 31, 2005 to comply. So the increase of independence will be gradual given different situations of different firms. We thus restrict our post-SOX sample to be only at year 2003, when the two groups of noncompliant firms roughly increase their independence the same relative to 2002, as our evidence suggests. We then compare whether the estimate of $\beta_{1}$ will be different for these two groups of firms. An optimality of the board independence for credit ratings would imply $\beta_{1}$ for the 
regression with the higher board independence is smaller or not significant, whereas $\beta_{1}$ of the lower board independence is larger and significant.

\section{Empirical Results}

\section{A. Board Independence and Credit Ratings}

We first test whether board independence matters for credit ratings, using specification (1). Table 3 presents the results. In model 1 through 4, we run the regressions with each of the noncompliant criteria separately (majority independent board and committee independence). The estimate for $\beta_{1}, 0.3$ in Model 1 is positive and significant at 5\% level, suggesting that increasing board independence have a positive impact on credit ratings on average. This represents a 0.3 notch upgrade for non-compliant firms relative to the compliant firms, which is also economically significant.

The results in Model 2 and 4 suggest that audit committee independence and nomination committee independence are also associated with higher ratings, but only the latter is weakly significant at $10 \%$ level, and have a much smaller magnitude than the full board independence. Interestingly, Model 3 suggests that having an independent compensation committee may even hurt the credit rating, even through the effect is not significant.

As firms may fail to comply with both full board independence and committee independence, there is possibility that the significant effect on full board independence is capturing other noncompliant effect, such as nomination committee independence, in Model 5 we include all these 
non-compliant criteria together. It can be seen that the coefficient on compensation committee non-compliance is negative and weakly significant at $10 \%$ level, suggesting that ceteris paribus, rating agencies do not value a fully independent compensation committees. The positive effect of full board independence and nomination committee independence is still present and even stronger, after netting out the negative effect of compensation committee independence. Audit committee independence continues to have no significant effect on credit ratings. This result is in contrast with that reported in Anderson, Mansi and Reeb (2004), who find audit committee independence reduces the cost of debt using the bond spread as the proxy. Aside from the possibility that the bond traders and rating agencies may value the same governance provision differently, we also note that the different sample year of the two studies may also contribute to this disparity. Anderson, Mansi, and Reeb (2004) use an earlier sample than ours (1993-1998) and their average audit committee independence is only 0.7 , while it is 0.90 in our sample, suggesting that the power of the tests for the two studies may be different. But we note that the fraction of firms which do not comply with the full board independence at $2002(0.12)$ is even smaller than such fraction for audit committee independence (0.29) based on Panel A of Table 1. Hence the positive and significant result we documented in Table 3 for the full board independence is even more notable.

The coefficients for the control variables are all highly significant and have the expected signs. It is notable that Volat is strongly associated with credit ratings even after controlling for the firm fixed effects. We also confirm that the positive effects for board independence in BS and ACL are largely due to their not including Volat as a control variable. 
Overall, the results in Table 3 suggest that rating agencies value board independence in their assessment of firms' credit ratings, aside from the consideration of committee independence. In addition, there is evidence that compensation committee independence is valued negatively and nomination committee independence positively by rating agencies.

\section{B. Optimality of Board Independence on Credit Ratings}

As described in the methodology section, we separate the non-compliant firms into two groups based on whether their board independence is above or below the sample median independence for all the non-compliant firms at 2002 (0.4). We then test the differential effect of the increase of board independence for these two sub-groups based on specification (1), conditional on that the increase of the board independence is similar across the two groups. It is expected that the group with higher independence would not have as significant an increase of the credit ratings as the group with lower independence.

Table 4 reports the results. Panel A lists the summary statistics of the two groups of noncompliant firms at 2002, and the difference for their increase of board independence over the subsequent years. The mean (median) independence for the low-independence group at 2002 is $0.301(0.308)$ and high-independence group $0.431(0.429)$. To make sure that both groups the board independence increases about the same, we restrict our post-SOX year to be only 2003, and test the increase of board independence between 2002 and 2003 for the two groups, and against the compliant group. The results in Panel A of Table 4 suggest that both groups increase their independence significantly relative to the compliant group $(0.109$ vs. 0.015 and 0.102 vs. 
0.015, respectively), but the increase are similar across the two groups. Thus, in Panel B of Table 4 we run the regressions for the two non-compliant groups separately, with only year 2003 as the post-SOX year. The results in Model 1 and 2 confirm our conjectures: the positive and significant result is only significant for the low-independence group. The coefficient for the highindependence group is positive but non-significant. The positive effect for the board independence on credit ratings is even stronger than the average non-compliant firms, 0.453 (significant at 1\% level) vs. 0.301 (significant at 5\% level), suggesting that for firms whose board is dominated by insiders, bringing independent directors will significantly decrease the credit risk relative to the firms whose board already have significant number of independent directors (though still non-compliant according to the listing standards).

The above analysis suffers from the concern that rating agencies may be forward looking in assigning the ratings. Therefore, they may have taken into the consideration that the lowindependence group will ultimately increase their independence more than the highindependence group hence assigning the ratings based on such projections, even though the actual increase of the independence is similar for both groups. Indeed, as Hovakimian, Kayhan, and Titman (2008) point out, in their rating criteria, rating agencies indeed state that they are forward looking. But the evidence in Hovakimian, Kayhan, and Titman (2008) suggests that ratings are predictable, which is inconsistent with the forward-looking statement. We check whether the strong positive effect of independence on credit ratings for low-independence group is due to the rating agencies' forward-looking behavior, by further examining the differential effect of the increase of independence on credit ratings for the two non-compliant groups beyond 
year 2003. If the rating agencies are indeed forward-looking, the further increase of independence for the low-independence group should not bring any change of ratings after 2003, the first years post SOX.

The evidence in Table 4 does not support the idea that the rating assignments are forwardlooking. Indeed, the t-tests in Panel A show that the two non-compliant groups further increased their board independence from 2003 to 2004, and the low-independence group increased independence significantly more than the high-independence group ( 0.103 vs. 0.043 , significant at $1 \%$ level). Combining the increase of the two years (2003 and 2004), the data suggest that for the median firm among the low-independence group, the board independence is 0.52 $(0.308+0.109+0.103)$, while for the median firm among the high-independence group, the board independence is 0.574 , we will later show that some independence level between these two numbers may be the optimal board independence for the average firm in the sample. In Model 3 and 4 of Panel B, we test whether there is differential effect of further increase of board independence for credit ratings for the two non-compliant groups post-2003. The specification is similar to equation (1) except we change the cutoff year to be 2003, instead of 2002 . Hence the year dummies also change accordingly. The results do not confirm that rating agencies are forward-looking: the coefficient on the interaction term for the low-independence group is still weakly significant, though of smaller magnitude. More interestingly, the coefficient for the highindependence group becomes negative, though not significant at conventional level. This suggests that further increase of independence for the already highly independent boards may not help, even hurt the credit ratings. 
Taken as a whole, the results in Table 4 suggest that there might be an optimal level of independence valued by the rating agencies. The closer independence is to that optimal level, the less positive effect the further increase of independence brings to credit ratings.

In Table 5, we further test this optimality by using different specifications of the model. In specification (1), instead of controlling for the interaction term between non-compliant dummy and post-SOX dummy, we directly control for the board independence. We add a quadratic term of board independence to test for the nonlinear effect. We also add the year effects since we observed in Figure 1 and 2 that ratings and independence follow opposite trend hence that might generate a negative relation between these two without controlling for time effects. Model 1 presents the results. Interestingly, both the independence and the quadratic terms are significant (at $5 \%$ and $1 \%$ level, respectively). And the coefficients on these two variables suggest that the optimal level of board independence is around $0.54(1.913 / 2 / 1.765)$. We note that in Panel B of Table 4, as discussed above, the independence for the median firm for the two non-compliant groups is 0.52 and 0.574 , respectively. Thus, it seems that the independence has surpassed the optimal level between 2003 and 2004 for the high-independence group but not the lowindependence group. This might explain the results we observed in Model 3 and 4 of Panel B in Table 4: the increase of the independence is positive and weakly significant for the lowindependence group but negative (though not significant) for the high-independence group.

In Model 2 of Table 5, we use a piecewise-linear specification as in Morck, Shleifer, and Vishny (1988) to further test the optimality. We created two variables based on the range of independence. Per_ind.0to 0.5 equals to independence when independence is less than 0.5 , and 
zero otherwise. Per_ind.0.5to1 equals to independence- 0.5 when independence is greater or equal to 0.5 , and zero otherwise. Other controls follow that of Model 1 . The results are consistent with the optimality of independence: independence is positively associated with credit ratings when the board is less than majority independent, and negatively associated with ratings when independence is beyond majority. The results in Model 5 further confirms that there is a optimal level of independence for credit ratings, and the optimal level is around 0.54 based on Model 1 .

\section{Tests of the Hypotheses on Optimality}

In this section we test the two hypotheses that may explain the optimality of independence for credit ratings, as we developed in part I. The key difference for the two hypotheses is the cost part: In ICH, the cost is the cost independent directors incurred in acquiring the firm-specific information. We thus follow prior literature (e.g., Boone et al. (2007) and Linck, Netter, and Yang (2008)) to include several proxies for the information cost. We use R\&D expenses, marketto-book ratio, and equity volatility as the proxies for the information acquisition costs. It is conjectured that for firms with high R\&D expenses, market-to-book ratio, and equity volatility, the directors may incur higher cost in acquiring the firm-specific information used in monitoring and advising functions, than firms with low $R \& D$ expenses, market-to-book ratio, and equity volatility.

Table 6 reports the regressions results. High $\mathrm{X}$ is a dummy variable that equals to one if $\mathrm{X}$ is above the median value of $\mathrm{X}$ in the sample, and zero otherwise, where $\mathrm{X}$ is one of the three proxies we discussed above. Low $\mathrm{X}$ is a dummy variable that equals to one if $\mathrm{X}$ is at or below 
the median value of $\mathrm{X}$ in the sample, and zero otherwise, where $\mathrm{X}$ is one of the three proxies we discussed above. We interact the High X dummy and Low X dummy with the interaction of board non-compliant dummy and post-SOX dummy. The results give mixed support for the ICH. While board independence seems to be effective in improving ratings for firms with low $R \& D$ expenses, and low market-to-book ratios, which is consistent with $\mathrm{ICH}$, it also improves the ratings of highly volatile firms, which is inconsistent with the hypothesis.

In $\mathrm{SEH}$, the optimal board independence is derived by balancing the benefit of reducing the private benefits of management and the cost of risk-shifting incentive by independent directors through their fiduciary duty to shareholders or explicit shareholdings. The conflict between shareholders and bondholders may be more acute when the firm is closer to default, as argued in Bradley and Chen (2009). Thus, if SEH holds, we should expect the increase of board independence mostly benefits investment-grade firms, which is more distant from default. We should also expect the increase of independence may benefit firms whose directors hold small amount of shares, hence not too aligned with shareholders. We thus interact the dummy for whether the firm is of investment-grade of speculative-grade, and whether directors' shareholding is above or below the sample median in 2002, with the interaction term as in equation (1). Table 7 reports the results. Model 1 shows that the positive and significant effect of board independence on credit ratings is only present for investment-grade firms. Model 2 indicates that such positive effect is only present for firms whose directors hold small shares. Both results are consistent with the SEH. Finally, in Model 3, we further interest the speculativegrade firm dummy with the high or low director shareholding dummy. The purpose is to further 
examine among the speculative-grade firms the differential effect of board independence on credit ratings given the different shareholding of directors. Again, the result is consistent with $\mathrm{SEH}$, as it shows that the increase of board independence still benefits the firms with speculativegrade firms, provided that the directors of those firms hold small amount of shares.

\section{Robustness Checks}

We conduct several robustness checks for our results. First, following Chhaochharia and Grinstein (2009), we use a balanced panel between 2000 and 2005 and all non-missing credit rating data for our regressions. As expected, the sample size dropped dramatically. Each year we only have 303 firms. But the major results of our analyses obtain qualitatively.

Second, as have been done by many other governance researches, we eliminate the finance \& utility firms from our sample, as many argue that these highly regulated industries may imply a minimal role for corporate governance. All our results remain and become even stronger.

Finally, we entertain with the cutoff year for the effect of the new regulations on firms' board structure. We use 2001 as the cutoff year for SOX and the results are similar. The rationale is that the COMPUSTAT fiscal year cutoff month is June of year $t$ through May of year $t+1$. Hence the year 2002 actually covers firms whose fiscal year end is before May, 2003. Since some regulations are enacted before SOX, such as NYSE's new rule to require its listed firms to have independent audit committee at 1999, we also use 1999 as the cutoff year for our study. The results also look similar. 


\section{Conclusion}

Credit rating is a very important variable as acknowledged by corporate managers. Yet the effect of corporate governance such as board independence on credit ratings is an underresearched area, with the current literature plagued by endogeneity concern. We use the passage of Sarbanes-Oxley Act and the associated change of new exchange listing standards as a natural experiment to tackle the endogeneity problem. Our difference-in-difference regression results suggest that the increase of board independence on average improves firm's credit ratings, but there might be an optimal level of independence above which rating agencies no longer value independence. We propose two hypotheses that may give rise to this interior solution of board independence in the firm value maximization problem: the information cost hypothesis, and the shareholder empowering hypothesis. Our evidence gives stronger support to the latter hypothesis than the former.

A natural question, as also asked in ACL, is why regulation such as stronger independence still benefits the firm's credit ratings? Why haven't the firms already pushed their independence to the optimal level to improve their ratings? ACL answers this question by resorting to CEO compensation. They argue that CEO of the firm with weak governance enjoys higher compensation, even though the weak governance hurts the firm's credit ratings. But this argument assumes that the governance structure is chosen by the management, which seems to be at odds with most literature, such as Hermalin and Weisbach (1998). Weber (2006) also argues that ACL's estimate of the economic cost of poor governance may be overstated. We leave the answer of this question for future research. 


\section{Table 1. Compliance Trend and Summary Statistics}

This table shows the compliance trend and summary statistics. The sample is an unbalanced panel for 1205 firms from 1996 to 2005 in the IRRC and COMPUSTAT databases. To save space, only statistics for years between 2000 and 2005 are shown. Panel A reports the compliance trend in terms of independent directors for the full board, audit committee independence, compensation committee independence, and nomination committee independence. An independent director is defined as a director who has not been an employee in the firm in the last 3 years, does not have business transactions with the firm, and has no family ties with employees of the firm. Panel B reports the summary statistics for credit ratings. Panel $\mathrm{C}$ reports the summary statistics for the financial variables that may determine credit ratings. Data over 2000 Size is the total assets. Lev is the long term debt plus debt in current liabilities divided by total assets. Roa is the return on assets defined by income before extraordinary items divided by total assets. Volat is the standard deviation of monthly stock returns for the past 60 months. In all the panels, numbers without parentheses are mean values, and numbers in parentheses are median values.

\begin{tabular}{|c|c|c|c|c|c|c|}
\hline \multicolumn{7}{|c|}{ Panel A: Compliance Trend } \\
\hline & 2000 & 2001 & 2002 & 2003 & 2004 & 2005 \\
\hline $\begin{array}{l}\text { Number of firms with non-missing data } \\
\text { for independent directors }\end{array}$ & 968 & 1146 & 1205 & 1137 & 1074 & 994 \\
\hline $\begin{array}{l}\text { Number of firms with less than majority } \\
\text { independent boards }\end{array}$ & 155 & 169 & 150 & 90 & 53 & 40 \\
\hline $\begin{array}{l}\text { Portion of firms with less than majority } \\
\text { independent boards }\end{array}$ & 0.16 & 0.15 & 0.12 & 0.08 & 0.05 & 0.04 \\
\hline $\begin{array}{l}\text { Portion of firms withnot fully } \\
\text { independent audit committees }\end{array}$ & 0.36 & 0.29 & 0.29 & 0.23 & 0.16 & 0.14 \\
\hline $\begin{array}{l}\text { Portion of firms withnot fully } \\
\text { independent compensation committees }\end{array}$ & 0.27 & 0.26 & 0.24 & 0.20 & 0.16 & 0.16 \\
\hline $\begin{array}{l}\text { Portion of firms withnot fully } \\
\text { independent nomination committees }\end{array}$ & 0.40 & 0.37 & 0.38 & 0.32 & 0.23 & 0.23 \\
\hline Percentage of independent directors & $\begin{array}{c}0.65 \\
(0.67)\end{array}$ & $\begin{array}{l}0.66 \\
(0.67)\end{array}$ & $\begin{array}{c}0.67 \\
(0.67)\end{array}$ & $\begin{array}{c}0.70 \\
(0.71)\end{array}$ & $\begin{array}{c}0.72 \\
(0.73)\end{array}$ & $\begin{array}{c}0.73 \\
(0.75)\end{array}$ \\
\hline Board size & $\begin{array}{l}9.77 \\
(9)\end{array}$ & $\begin{array}{c}9.48 \\
(9)\end{array}$ & $\begin{array}{l}9.40 \\
(9)\end{array}$ & $\begin{array}{l}9.47 \\
(9)\end{array}$ & $\begin{array}{l}9.51 \\
(9)\end{array}$ & $\begin{array}{l}9.55 \\
(9)\end{array}$ \\
\hline Portion of NYSE firms & 0.74 & 0.70 & 0.68 & 0.70 & 0.71 & 0.72 \\
\hline \multicolumn{7}{|c|}{ Panel B: Credit Ratings } \\
\hline & 2000 & 2001 & 2002 & 2003 & 2004 & 2005 \\
\hline $\begin{array}{l}\text { Number of firms with non-missing data } \\
\text { for credit ratings }\end{array}$ & 590 & 669 & 710 & 695 & 666 & 607 \\
\hline Credit Ratings & $\begin{array}{c}14.75 \\
(15)\end{array}$ & $\begin{array}{c}14.37 \\
(14)\end{array}$ & $\begin{array}{c}13.95 \\
(14)\end{array}$ & $\begin{array}{c}13.86 \\
(14)\end{array}$ & $\begin{array}{c}13.88 \\
(14)\end{array}$ & $\begin{array}{c}13.99 \\
(14)\end{array}$ \\
\hline \multicolumn{7}{|c|}{ Panel C: Financial Characteristics } \\
\hline & 2000 & 2001 & 2002 & 2003 & 2004 & 2005 \\
\hline Size (\$millions) & $\begin{array}{l}13449 \\
(1923)\end{array}$ & $\begin{array}{l}14567 \\
(1765)\end{array}$ & $\begin{array}{l}14765 \\
(1745)\end{array}$ & $\begin{array}{l}16292 \\
(2024)\end{array}$ & $\begin{array}{l}19581 \\
(2343)\end{array}$ & $\begin{array}{l}20643 \\
(2506)\end{array}$ \\
\hline Lev & $\begin{array}{l}0.25 \\
(0.25)\end{array}$ & $\begin{array}{c}0.24 \\
(0.24)\end{array}$ & $\begin{array}{c}0.23 \\
(0.23)\end{array}$ & $\begin{array}{c}0.22 \\
(0.22)\end{array}$ & $\begin{array}{c}0.21 \\
(0.20)\end{array}$ & $\begin{array}{c}0.20 \\
(0.19)\end{array}$ \\
\hline ROA & $\begin{array}{c}0.05 \\
(0.05)\end{array}$ & $\begin{array}{c}0.01 \\
(0.03)\end{array}$ & $\begin{array}{c}0.01 \\
(0.03)\end{array}$ & $\begin{array}{c}0.03 \\
(0.04)\end{array}$ & $\begin{array}{c}0.05 \\
(0.05)\end{array}$ & $\begin{array}{c}0.05 \\
(0.05)\end{array}$ \\
\hline Volat & $\begin{array}{c}0.12 \\
(0.11)\end{array}$ & $\begin{array}{c}0.14 \\
(0.12)\end{array}$ & $\begin{array}{c}0.15 \\
(0.13)\end{array}$ & $\begin{array}{c}0.14 \\
(0.12)\end{array}$ & $\begin{array}{c}0.13 \\
(0.11)\end{array}$ & $\begin{array}{c}0.11 \\
(0.10)\end{array}$ \\
\hline
\end{tabular}




\section{Table 2. Numerical Coding of Credit Ratings}

\begin{tabular}{cccc}
\hline S\&P Rating & COMPUSTAT data280 & Numerical Coding & Grade \\
\hline D & 27 & 1 & Speculative \\
C & 24 & 2 & Speculative \\
CC & 23 & 3 & Speculative \\
CCC- & 21 & 4 & Speculative \\
CCC & 20 & 5 & Speculative \\
CCC+ & 19 & 6 & Speculative \\
B- & 18 & 7 & Speculative \\
B & 17 & 8 & Speculative \\
B+ & 16 & 9 & Speculative \\
BB- & 15 & 10 & Speculative \\
BB & 14 & 11 & Speculative \\
BB+ & 13 & 12 & Speculative \\
BBB- & 12 & 13 & Investment \\
BBB & 11 & 14 & Investment \\
BBB + & 10 & 15 & Investment \\
A- & 9 & 16 & Investment \\
A & 8 & 17 & Investment \\
A+ & 7 & 18 & Investment \\
AA- & 6 & 19 & Investment \\
AA & 5 & 20 & Investment \\
AA+ & 4 & 21 & Investment \\
AAA & 2 & 22 & Investment \\
\hline
\end{tabular}




\section{Table 3. Board Compliance and Credit Ratings}

This table shows the results of panel regressions, where the dependent variable is the numerical credit ratings as defined in Table 2. The sample is an unbalanced panel for 1205 firms from 1996 to 2005. Size is the natural $\log$ of total assets. Lev is the long term debt plus debt in current liabilities divided by total assets. Roa is the return on assets defined by income before extraordinary items divided by total assets. Volat is the standard deviation of monthly stock returns for the past 60 months. Dummy(per ind $<0.5$ '02) is a dummy variable that equals to one if the firm did not have majority independent director in 2002, and zero otherwise. Dummy(ind_audit=0 '02) is a dummy variable that equals to one if the firm did not have a fully independent audit committee in 2002, and zero otherwise. Dummy(ind_comp=0 '02) is a dummy variable that equals to one if the firm did not have a fully independent compensation committee in 2002, and zero otherwise. Dummy(ind_nom=0 '02) is a dummy variable that equals to one if the firm did not have a fully independent nomination committee in 2002, and zero otherwise. Post SOX is a dummy variable that equals to one if the year is between 2003 and 2005, and zero otherwise. Before SOX is a dummy variable that equals to one if the year is between 1996 and 2002, and zero otherwise. T-statistics are in the parentheses. Standard errors are adjusted for robustness and clustered at the firm level. *,**, and *** indicate significance at $10 \%, 5 \%$, and $1 \%$ levels, respectively.

\begin{tabular}{|c|c|c|c|c|c|}
\hline $\begin{array}{l}\text { Dependent variable: } \\
\text { Credit Rating }\end{array}$ & (1) & (2) & (3) & (4) & (5) \\
\hline Dummy(per_ind $<0.5$ '02) * Post SOX & $\begin{array}{l}0.301^{* *} \\
(2.280)\end{array}$ & & & & $\begin{array}{c}0.375^{* *} \\
(2.451)\end{array}$ \\
\hline Dummy(ind_audit $=0$ '02) * Post SOX & & $\begin{array}{c}0.086 \\
(0.881)\end{array}$ & & & $\begin{array}{c}0.035 \\
(0.342)\end{array}$ \\
\hline Dummy(ind_comp $=0$ '02) * Post SOX & & & $\begin{array}{c}-0.080 \\
(-0.688)\end{array}$ & & $\begin{array}{l}-0.250^{*} \\
(-1.925)\end{array}$ \\
\hline Dummy(ind_nom $=0$ '02) * Post SOX & & & & $\begin{array}{l}0.157^{*} \\
(1.735)\end{array}$ & $\begin{array}{l}0.195 * * \\
(2.071)\end{array}$ \\
\hline Size $*$ Before SOX & $\begin{array}{c}0.437 * * * \\
(4.837)\end{array}$ & $\begin{array}{c}0.441 * * * \\
(4.888)\end{array}$ & $\begin{array}{c}0.445 * * * \\
(4.938)\end{array}$ & $\begin{array}{c}0.445 * * * \\
(4.939)\end{array}$ & $\begin{array}{c}0.437 * * * \\
(4.839)\end{array}$ \\
\hline Size $*$ Post SOX & $\begin{array}{c}0.360 * * * \\
(4.176)\end{array}$ & $\begin{array}{c}0.361 * * * \\
(4.189)\end{array}$ & $\begin{array}{c}0.369 * * * \\
(4.287)\end{array}$ & $\begin{array}{c}0.363 * * * \\
(4.218)\end{array}$ & $\begin{array}{c}0.354 * * * \\
(4.099)\end{array}$ \\
\hline Lev * Before SOX & $\begin{array}{c}-2.854 * * * \\
(-8.353)\end{array}$ & $\begin{array}{c}-2.865 * * * \\
(-8.328)\end{array}$ & $\begin{array}{c}-2.873 * * * \\
(-8.310)\end{array}$ & $\begin{array}{c}-2.844 * * * \\
(-8.300)\end{array}$ & $\begin{array}{c}-2.847 * * * \\
(-8.358)\end{array}$ \\
\hline Lev * Post SOX & $\begin{array}{c}-3.492 * * * \\
(-8.305)\end{array}$ & $\begin{array}{c}-3.504 * * * \\
(-8.310)\end{array}$ & $\begin{array}{c}-3.494 * * * \\
(-8.245)\end{array}$ & $\begin{array}{c}-3.516^{* * *} \\
(-8.293)\end{array}$ & $\begin{array}{c}-3.452 * * * \\
(-8.245)\end{array}$ \\
\hline Roa * Before SOX & $\begin{array}{c}2.135^{* * * *} \\
(3.896)\end{array}$ & $\begin{array}{c}2.113 * * * \\
(3.864)\end{array}$ & $\begin{array}{c}2.107 * * * \\
(3.854)\end{array}$ & $\begin{array}{c}2.132 * * * \\
(3.896)\end{array}$ & $\begin{array}{c}2.166^{* * *} \\
(3.961)\end{array}$ \\
\hline Roa $*$ Post SOX & $\begin{array}{c}3.788 * * * \\
(4.969)\end{array}$ & $\begin{array}{c}3.766 * * * \\
(4.920)\end{array}$ & $\begin{array}{l}3.800 * * * \\
(4.999)\end{array}$ & $\begin{array}{l}3.742 * * * \\
(4.972)\end{array}$ & $\begin{array}{c}3.777 * * * \\
(5.011)\end{array}$ \\
\hline Volat* Before SOX & $\begin{array}{c}-16.531 * * * \\
(-11.592)\end{array}$ & $\begin{array}{c}-16.684 * * * \\
(-11.672)\end{array}$ & $\begin{array}{c}-16.726^{* * *} \\
(-11.687)\end{array}$ & $\begin{array}{c}-16.686^{* * *} \\
(-11.675)\end{array}$ & $\begin{array}{c}-16.514^{* * *} \\
(-11.605)\end{array}$ \\
\hline Volat* Post SOX & $\begin{array}{c}-17.149 * * * \\
(-10.600)\end{array}$ & $\begin{array}{c}-17.108 * * * \\
(-10.520)\end{array}$ & $\begin{array}{c}-17.119 * * * \\
(-10.565)\end{array}$ & $\begin{array}{c}-17.175^{* * * *} \\
(-10.542)\end{array}$ & $\begin{array}{c}-17.078 * * * \\
(-10.558)\end{array}$ \\
\hline Fixed firm effect & Yes & Yes & Yes & Yes & Yes \\
\hline $\mathrm{N}$ & 5883 & 5883 & 5883 & 5883 & 5883 \\
\hline Adjusted R2 & 0.33 & 0.33 & 0.33 & 0.33 & 0.33 \\
\hline
\end{tabular}




\section{Table 4. Different Board Non-Compliance and Credit Ratings}

This table shows the difference in the increase of independent directors for different non-compliant firms, and the results of panel regressions where the dependent variable is the numerical credit ratings as defined in Table 2. Panel A tests the difference in the increase of board independence for non-compliant firms differentiated by greater or smaller than the median board independence for all the non-compliant firms in 2002 (0.4), from 2002 to 2003, and from 2003 to 2004, respectively. Per_ind $<0.4$ ' 02 refers to the firms whose board independence is less than 0.4 in 2002. $0.4<=$ Per_ind $<0.5$ ' 02 refers to the firms whose board independence is less than majority but greater or equal than 0.4 in 2002. Per_ind $>=0.5$ ' 02 refers to the firms whose board independence is greater than majority in 2002. Panel B tests the difference in the change of credit ratings for different non-compliant firms. The sample for model 1 and 2 is an unbalanced panel for 1205 firms from 1996 to 2003. The sample for model 3 and 4 is an unbalanced panel for 1205 firms from 1996 to 2004. Dummy(per_ind <0.4 '02) is a dummy variable that equals to one if the percentage of independent directors is less than 0.4 (the median independence for all the firms in 2002) in 2002, and zero if independence is greater than majority. $\operatorname{Dummy}(0.4<=$ per_ind $<0.5$ ' 02$)$ is a dummy variable that equals to one if the percentage of independent directors is less than majority but greater than 0.4 in 2002, and zero if independence is greater than majority. Dummy(year='03) is a dummy variable that equals to one if the year is 2003, and zero otherwise. Dummy(year='04) is a dummy variable that equals to one if the year is 2004, and zero otherwise. Dummy (year $<=$ '03) is a dummy variable that equals to one if the year is before 2003 (including 2003), and zero otherwise. Definitions for other variables follow Table 3. T-statistics are in the parentheses. Standard errors are adjusted for robustness and clustered at the firm level. *,**, and *** indicate significance at $10 \%, 5 \%$, and $1 \%$ levels, respectively.

\section{Panel A: Increase of Board Independence for Different Non-Compliant Firms}

\begin{tabular}{|c|c|c|c|c|}
\hline 2002 & Per_ind $<0.4$ '02 & $0.4<=$ Per_ind $<0.5{ }^{\prime} 02$ & & \\
\hline $\mathrm{N}$ & 72 & 78 & & \\
\hline Mean & 0.301 & 0.431 & & \\
\hline Median & 0.308 & 0.429 & & \\
\hline $2002-2003$ & Per_ind $>=0.5$ ' 02 & Per_ind $<0.4$ ' 02 & Difference & $\mathrm{p}$-value for difference \\
\hline $\begin{array}{l}N \\
\Delta \text { per ind }\end{array}$ & $\begin{array}{c}992 \\
0.015\end{array}$ & $\begin{array}{c}68 \\
0.109\end{array}$ & & $0000 * * *$ \\
\hline$\Delta$ per_ind & Per_ind $>=0.5$ ' 02 & $0.4<=$ Per_ind $<0.5{ }^{\prime} 02$ & $\begin{array}{c}0.094 \\
\text { Difference }\end{array}$ & $\mathrm{p}$-value for difference \\
\hline $\mathrm{N}$ & 992 & 71 & & \\
\hline$\Delta$ per_ind & $\begin{array}{c}0.015 \\
0.4<=\text { Per_ind }<0.5 \text { '02 }\end{array}$ & $\begin{array}{c}0.102 \\
\text { Per_ind }<0.4 \text { '02 }\end{array}$ & $\begin{array}{c}0.087 \\
\text { Difference }\end{array}$ & $\begin{array}{c}0.000^{* * *} \\
\text { p-value for difference }\end{array}$ \\
\hline $\mathrm{N}$ & 71 & 68 & & \\
\hline$\Delta$ per_ind & 0.102 & 0.109 & 0.008 & 0.690 \\
\hline $\begin{array}{l}2003-2004 \\
N\end{array}$ & $\begin{array}{c}\text { Per_ind }>=0.5 \text { '02 } \\
942\end{array}$ & $\begin{array}{c}\text { Per_ind }<0.4 \text { '0 } 02 \\
66\end{array}$ & Difference & $\mathrm{p}$-value for difference \\
\hline$\Delta$ per_ind & $\begin{array}{c}0.013 \\
\text { Per_ind }>=0.5{ }^{`} 02\end{array}$ & $\begin{array}{c}0.103 \\
0.4<=\text { Per_ind }<0.5{ }^{\prime} 02\end{array}$ & $\begin{array}{c}0.090 \\
\text { Difference }\end{array}$ & $\begin{array}{c}0.000^{* * *} \\
\mathrm{p} \text {-value for difference }\end{array}$ \\
\hline $\mathrm{N}$ & 942 & 63 & & \\
\hline$\Delta$ per_ind & $\begin{array}{c}0.013 \\
0.4<=\text { Per_ind }<0.5 \text { '02 }\end{array}$ & $\begin{array}{c}0.043 \\
\text { Per_ind }<0.4 \text { '02 }\end{array}$ & $\begin{array}{c}0.030 \\
\text { Difference }\end{array}$ & $\begin{array}{c}0.007^{* * *} \\
\mathrm{p} \text {-value for difference }\end{array}$ \\
\hline $\mathrm{N}$ & 63 & 66 & & \\
\hline$\Delta$ per_ind & 0.043 & 0.103 & 0.060 & $0.002 * * *$ \\
\hline
\end{tabular}

(continued) 
Table 4-Continued

\begin{tabular}{|c|c|c|c|c|}
\hline \multicolumn{4}{|c|}{ Table 4 -Continued } & Panel B: Different Non-Compliant Board Independence and Credit Ratings \\
\hline Dependent variable: & $1996<=$ & $=2003$ & 199 & $<=2004$ \\
\hline Credit Rating & $(1)$ & $(2)$ & $(3)$ & (4) \\
\hline $\begin{array}{l}\operatorname{Dummy}(0.4<=\text { per_ind }<0.5 ' 02) \\
* \text { Dummy }(\text { year='03) }\end{array}$ & $\begin{array}{c}0.148 \\
(1.030)\end{array}$ & & & \\
\hline Dummy(per ind $<0.4$ '02) * & & $0.453 * * *$ & & \\
\hline Dummy $($ year $=’ 03)$ & & $(3.547)$ & & \\
\hline $\operatorname{Dummy}(0.4<=$ per_ind $<0.5$ '02) & & & -0.040 & \\
\hline * Dummy $($ year=’04) & & & $(-0.157)$ & \\
\hline Dummy(per_ind $<0.4 \cdot 02) *$ & & & & $0.307^{*}$ \\
\hline Dummy(year=’04) & & & & $(1.943)$ \\
\hline Size * Before SOX & $\begin{array}{c}0.449 * * * \\
(4.260)\end{array}$ & $\begin{array}{c}0.463 * * * \\
(4.358)\end{array}$ & & \\
\hline Size * Dummy $($ year='03) & $\begin{array}{l}0.402 * * * \\
(3.971)\end{array}$ & $\begin{array}{l}0.420 * * * \\
(4.118)\end{array}$ & & \\
\hline Lev * Before SOX & $\begin{array}{c}-3.339 * * * \\
(-8.503)\end{array}$ & $\begin{array}{c}-3.146 * * * \\
(-8.089)\end{array}$ & & \\
\hline Lev * Dummy $($ year='03) & $\begin{array}{c}-4.066 * * * \\
(-8.086)\end{array}$ & $\begin{array}{l}-3.897 * * * \\
(-7.733)\end{array}$ & & \\
\hline Roa $*$ Before SOX & $\begin{array}{l}2.009 * * * \\
(3.012)\end{array}$ & $\begin{array}{l}2.110 * * * \\
(3.149)\end{array}$ & & \\
\hline Roa * Dummy (year='03) & $\begin{array}{c}4.748 * * * \\
(3.697)\end{array}$ & $\begin{array}{l}4.722 * * * \\
(3.690)\end{array}$ & & \\
\hline Volat $*$ Before SOX & $\begin{array}{c}-18.228 * * * \\
(-10.311)\end{array}$ & $\begin{array}{l}-18.123 * * * \\
(-10.275)\end{array}$ & & \\
\hline Volat * Dummy $($ year='03) & $\begin{array}{c}-18.366 * * * \\
(-9.068)\end{array}$ & $\begin{array}{c}-18.501 * * * \\
(-9.166)\end{array}$ & & \\
\hline Size * Dummy $($ year<='03) & & & $\begin{array}{c}0.359 * * * \\
(3.605)\end{array}$ & $\begin{array}{l}0.366^{* * * *} \\
(3.659)\end{array}$ \\
\hline Size * Dummy (year='04) & & & $\begin{array}{l}0.295 * * * \\
(3.003)\end{array}$ & $\begin{array}{l}0.309 * * * \\
(3.124)\end{array}$ \\
\hline Lev * Dummy $($ year $<=$ '03 $)$ & & & $\begin{array}{l}-3.070 * * * \\
(-8.377)\end{array}$ & $\begin{array}{l}-2.865 * * * \\
(-7.981)\end{array}$ \\
\hline Lev * Dummy (year='04) & & & $\begin{array}{l}-3.617 * * * \\
(-6.959)\end{array}$ & $\begin{array}{l}-3.414 * * * \\
(-6.706)\end{array}$ \\
\hline Roa $*$ Dummy $($ year $<=$ 03 $)$ & & & $\begin{array}{l}2.322 * * * \\
(3.564)\end{array}$ & $\begin{array}{c}2.414 * * * \\
(3.696)\end{array}$ \\
\hline Roa * Dummy (year=’04) & & & $\begin{array}{c}4.760 * * * \\
(4.687)\end{array}$ & $\begin{array}{c}4.550 * * * \\
(4.763)\end{array}$ \\
\hline Volat $*$ Dummy $($ year $<=$ '03 $)$ & & & $\begin{array}{c}-20.180 * * * \\
(-11.232)\end{array}$ & $\begin{array}{c}-19.998 * * * \\
(-11.149)\end{array}$ \\
\hline Volat * Dummy $($ year='04) & & & $\begin{array}{c}-21.380 * * * \\
(-10.779)\end{array}$ & $\begin{array}{c}-21.574 * * * \\
(-10.898)\end{array}$ \\
\hline Fixed firm effect & Yes & Yes & Yes & Yes \\
\hline $\mathrm{N}$ & 4431 & 4394 & 5062 & 5028 \\
\hline Adjusted R2 & 0.32 & 0.32 & 0.32 & 0.32 \\
\hline
\end{tabular}




\section{Table 5. Optimal Board Independence and Credit Ratings}

This table shows the results of panel regressions, where the dependent variable is the numerical credit ratings as defined in Table 2. The sample is an unbalanced panel for 1205 firms from 1996 to 2005. Per_ind is the percentage of independent directors. Per_ind ${ }^{2}$ is the square term of Per_ind. Per_ind.0to 0.5 is a piecewise linear function of Per_ind. It equals to Per_ind if Per_ind $<0.5$, and 0 if Per_ind $>=0.5$. Per_ind.0.5to 1 is a piecewise linear function of Per_ind. It equals to 0 if Per_ind $<0.5$, and Per_ind- 0.5 if $\overline{P e r}$ ind $>=0.5$. Definitions for other variables follow Table 3. T-statistics are in the parentheses. Standard errors are adjusted for robustness and clustered at the firm level. *, **, and $* * *$ indicate significance at $10 \%, 5 \%$, and $1 \%$ levels, respectively.

\begin{tabular}{lcc}
\hline Dependent variable: & $(1)$ & $(2)$ \\
Credit Rating & $1.913^{* *}$ & \\
\hline & $(2.413)$ & \\
Per_ind & $-1.765^{* * *}$ & \\
Per_ind ${ }^{2}$ & $(-2.832)$ & $0.744^{*}$ \\
& & $(1.691)$ \\
Per_ind.0to0.5 & $-0.566^{* *}$ \\
Per_ind.0.5to1 & & $(-2.256)$ \\
& & $0.597 * * *$ \\
Size * Before SOX & $0.595^{* * *}$ & $(5.358)$ \\
& $(5.349)$ & $0.630^{* * *}$ \\
Size * Post SOX & $0.629^{* * *}$ & $(5.931)$ \\
& $(5.927)$ & $-3.288^{* * *}$ \\
Lev* Before SOX & $-3.285^{* * *}$ & $(-8.735)$ \\
& $(-8.706)$ & $-3.590^{* * *}$ \\
Lev* Post SOX & $-3.587 * * *$ & $(-8.161)$ \\
& $(-8.161)$ & $1.719^{* * *}$ \\
Roa* Before SOX & $1.723^{* * *}$ & $(2.939)$ \\
& $(2.939)$ & $4.483 * * *$ \\
Roa * Post SOX & $4.477^{* * *}$ & $(5.446)$ \\
& $(5.439)$ & $-16.915^{* * *}$ \\
Volat* Before SOX & $-16.904^{* * *}$ & $(-9.123)$ \\
& $(-9.139)$ & $-17.028^{* * *}$ \\
Volat* Post SOX & $-17.053^{* * *}$ & $(-8.279)$ \\
Fixed firm effect & $(-8.319)$ & Yes \\
Fixed year effect & Yes & Yes \\
N & Yes & 5883 \\
Adjusted R2 & 5883 & 0.36 \\
\hline
\end{tabular}




\section{Table 6. Test of Information Cost Hypothesis}

This table shows the results of panel regressions, where the dependent variable is the numerical credit ratings as defined in Table 2. The sample is an unbalanced panel for 1205 firms from 1996 to 2005. High R\&D is a dummy variable that equals to one if the firm's R\&D expense is greater than the sample median in 2002, and zero otherwise. Low $R \& D$ is a dummy variable that equals to one if the firm's $R \& D$ expense is at or below the sample median in 2002, and zero otherwise. High MB is a dummy variable that equals to one if the firm's market-to-book ratio is greater than the sample median in 2002, and zero otherwise. Low MB is a dummy variable that equals to one if the firm's market-to-book ratio is at or below the sample median in 2002, and zero otherwise. High Volatility is a dummy variable that equals to one if the standard deviation of the firm's past 60 months' stock returns is greater than the sample median in 2002, and zero otherwise. Low Volatility is a dummy variable that equals to one if the standard deviation of the firm's past 60 months' stock returns is at or below the sample median in 2002, and zero otherwise. Definitions for other variables follow Table 3. T-statistics are in the parentheses. Standard errors are adjusted for robustness and clustered at the firm level. *,**, and $* * *$ indicate significance at $10 \%, 5 \%$, and $1 \%$ levels, respectively.

\begin{tabular}{|c|c|c|c|}
\hline $\begin{array}{l}\text { Dependent variable: } \\
\text { Credit Rating }\end{array}$ & (1) & (2) & (3) \\
\hline High R\&D * Dummy(per_ind $<0.5$ '02) * Post SOX & $\begin{array}{c}0.371 \\
(1.232)\end{array}$ & & \\
\hline Low R\&D * Dummy(per_ind $<0.5$ '02) * Post SOX & $\begin{array}{l}0.280^{* *} \\
(2.010)\end{array}$ & & \\
\hline High MB * Dummy(per_ind $<0.5$ '02) * Post SOX & & $\begin{array}{c}0.308 \\
(1.608)\end{array}$ & \\
\hline Low MB * Dummy(per_ind $<0.5$ '02) * Post SOX & & $\begin{array}{l}0.293^{*} \\
(1.795)\end{array}$ & \\
\hline High Volatility * Dummy(per_ind $<0.5$ '02) * Post SOX & & & $\begin{array}{c}0.392 * * * \\
(2.822)\end{array}$ \\
\hline Low Volatility * Dummy(per_ind $<0.5$ '02) * Post SOX & & & $\begin{array}{c}0.214 \\
(1.005)\end{array}$ \\
\hline Size * Before SOX & $\begin{array}{c}0.437 * * * \\
(4.836)\end{array}$ & $\begin{array}{c}0.437 * * * \\
(4.833)\end{array}$ & $\begin{array}{c}0.435 * * * \\
(4.799)\end{array}$ \\
\hline Size * Post SOX & $\begin{array}{c}0.360 * * * \\
(4.175)\end{array}$ & $\begin{array}{c}0.360 * * * \\
(4.172)\end{array}$ & $\begin{array}{c}0.359 * * * \\
(4.162)\end{array}$ \\
\hline Lev * Before SOX & $\begin{array}{c}-2.855 * * * \\
(-8.357)\end{array}$ & $\begin{array}{c}-2.855 * * * \\
(-8.338)\end{array}$ & $\begin{array}{c}-2.850 * * * \\
(-8.349)\end{array}$ \\
\hline Lev * Post SOX & $\begin{array}{c}-3.489 * * * \\
(-8.303)\end{array}$ & $\begin{array}{c}-3.492^{* * * *} \\
(-8.305)\end{array}$ & $\begin{array}{c}-3.491 * * * \\
(-8.296)\end{array}$ \\
\hline Roa * Before SOX & $\begin{array}{c}2.136^{* * * *} \\
(3.897)\end{array}$ & $\begin{array}{c}2.135^{* * *} \\
(3.897)\end{array}$ & $\begin{array}{c}2.142 * * * \\
(3.907)\end{array}$ \\
\hline Roa * Post SOX & $\begin{array}{c}3.788 * * * \\
(4.969)\end{array}$ & $\begin{array}{c}3.786^{* * * *} \\
(4.941)\end{array}$ & $\begin{array}{c}3.782 * * * \\
(4.964)\end{array}$ \\
\hline Volat* Before SOX & $\begin{array}{c}-16.530 * * * \\
(-11.588)\end{array}$ & $\begin{array}{c}-16.531 * * * \\
(-11.590)\end{array}$ & $\begin{array}{c}-16.489 * * * \\
(-11.553)\end{array}$ \\
\hline Volat * Post SOX & $\begin{array}{c}-17.151^{* * *} \\
(-10.601)\end{array}$ & $\begin{array}{c}-17.150^{* * * *} \\
(-10.600)\end{array}$ & $\begin{array}{c}-17.213^{* * *} \\
(-10.606)\end{array}$ \\
\hline Fixed firm effect & Yes & Yes & Yes \\
\hline $\mathrm{N}$ & 5883 & 5883 & 5883 \\
\hline Adjusted R2 & 0.33 & 0.33 & 0.33 \\
\hline
\end{tabular}




\section{Table 7. Test of Shareholder Empowering Hypothesis}

This table shows the results of panel regressions, where the dependent variable is the numerical credit ratings as defined in Table 2. The sample is an unbalanced panel for 1205 firms from 1996 to 2005. Junk is a dummy variable that equals to one if the firm's credit rating is at or below BB+ by S\&P in 2002, and zero otherwise. Invest is a dummy variable that equals to one if the firm's credit rating is at or above BBB- by S\&P in 2002, and zero otherwise. High Independent Director Ownership is a dummy variable that equals to one if the average independent director share ownership is above the median value in 2002, and zero otherwise. Low Independent Director Ownership is a dummy variable that equals to one if the average independent director share ownership is at or below the median value in 2002, and zero otherwise. Definitions for other variables follow Table 3. T-statistics are in the parentheses. Standard errors are adjusted for robustness and clustered at the firm level. *,**, and *** indicate significance at $10 \%, 5 \%$, and $1 \%$ levels, respectively.

Dependent variable:

Credit Rating

(1)

(2)

(3)

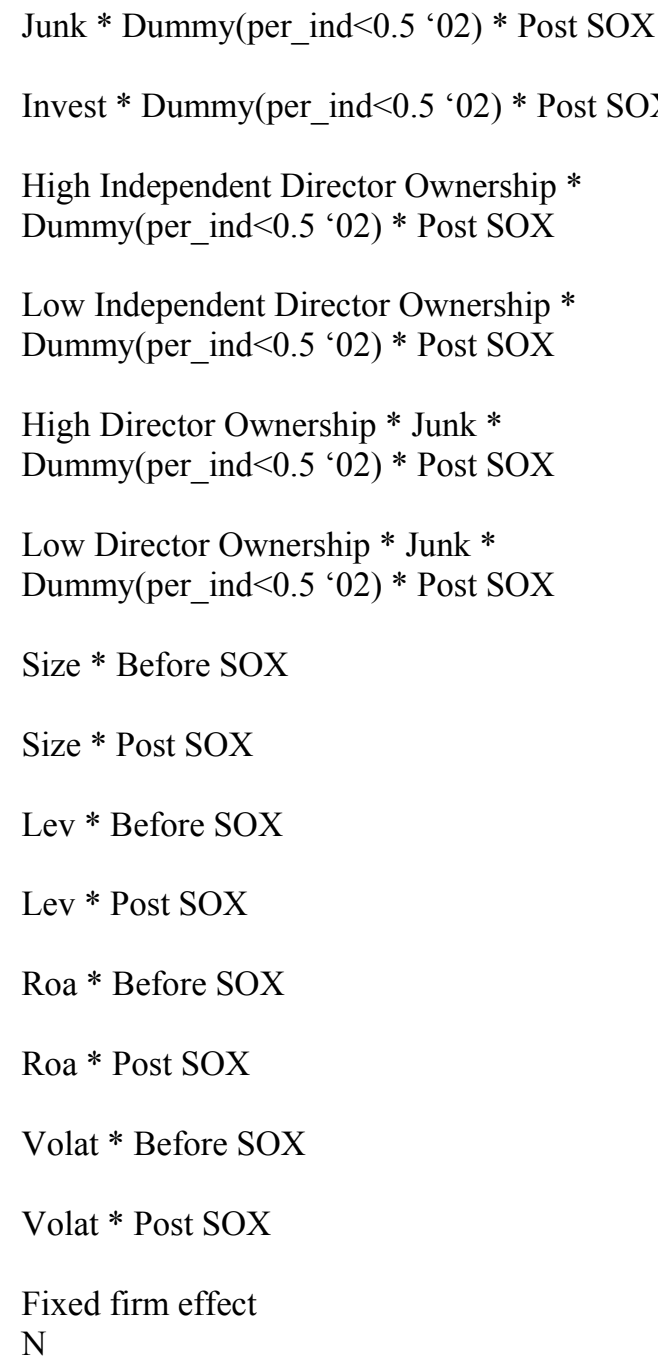

High Independent Director Ownership *

Dummy(per_ind $<0.5$ '02) * Post SOX

Low Independent Director Ownership *

Dummy(per_ind $<0.5$ '02) * Post SOX

High Director Ownership * Junk *

Dummy(per_ind $<0.5$ '02) * Post SOX

Low Director Ownership * Junk *

Dummy(per_ind $<0.5$ '02) * Post SOX

Size * Before SOX

Size * Post SOX

Lev * Before SOX

Lev * Post SOX

Roa * Before SOX

Roa * Post SOX

Volat * Before SOX

Volat * Post SOX

Fixed firm effect

$\mathrm{N}$

0.196

$0.440 * * *$

(4.859)

$0.360^{* * *}$

(4.179)

$-2.875^{* * *}$

$(-8.335)$

$-3.495^{* * *}$

(-8.322)

$2.129 * * *$

(3.875)

$3.768^{* * *}$

(4.934)

$-16.586^{* * *}$

(-11.592)

$-17.086^{* * *}$

(-10.542)

Yes

5883

$0.437 * * *$
$(4.826)$
$0.359 * * *$
$(4.161)$
$-2.863 * * *$
$(-8.362)$
$-3.499 * * *$
$(-8.312)$
$2.132 * * *$
$(3.889)$
$3.789 * * *$
$(4.970)$
$-16.542 * * *$
$(-11.595)$
$-17.141 * * *$
$(-10.600)$
Yes
5883
0.33

$0.438 * * *$

$0.359 * * *$

(4.158)

$-2.885^{* * *}$

$(-8.350)$

$-3.504 * * *$

(-8.333)

$2.127^{* * *}$

(3.871)

$3.766 * * *$

(4.933)

$-16.572 * * *$

(-11.589)

$-17.092 * * *$

(-10.544)

Yes

0.33

5883

0.33 
Figure 1. Time Trend for Proportion of Independent Directors

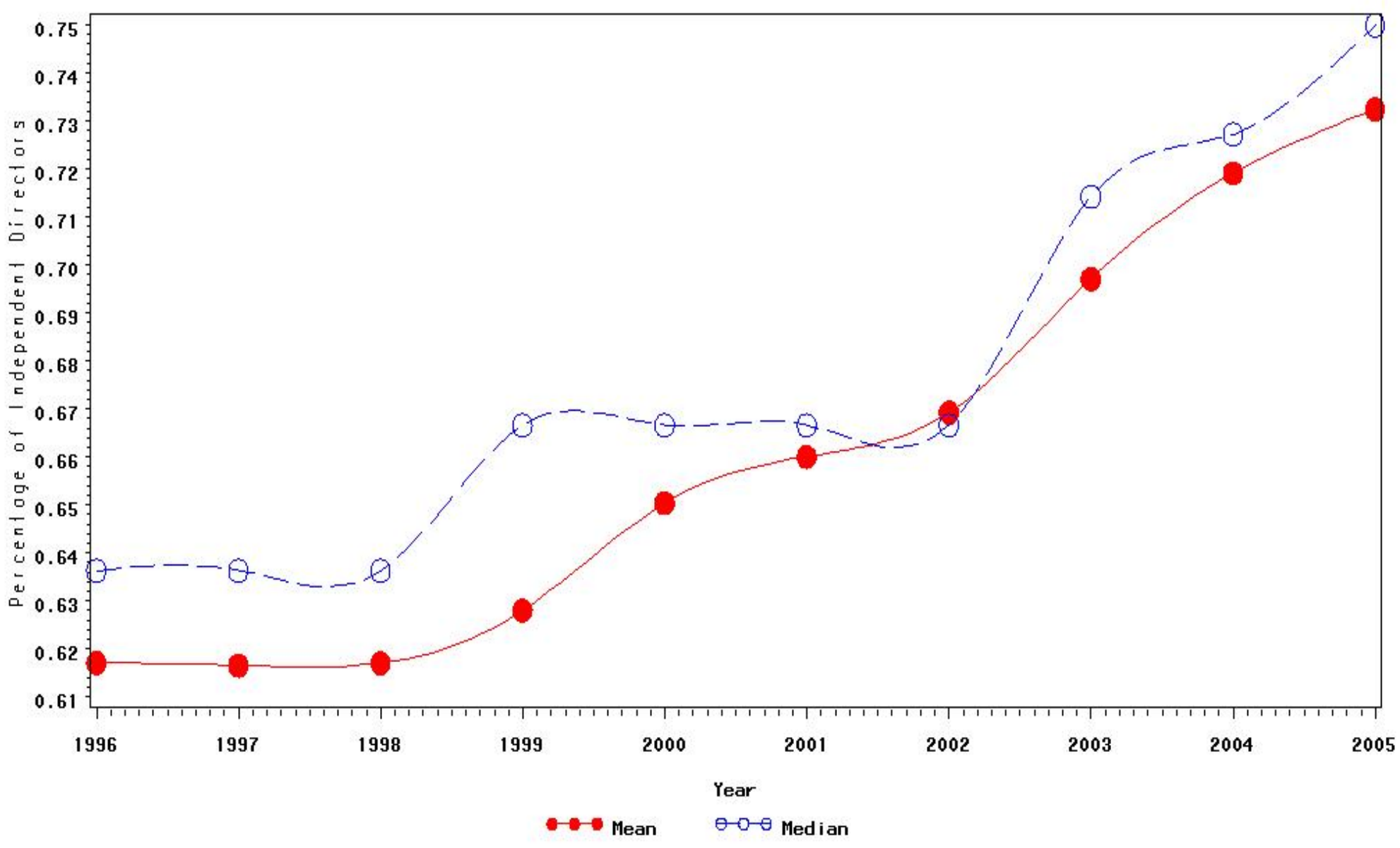


Figure 2. Time Trend for Credit Ratings

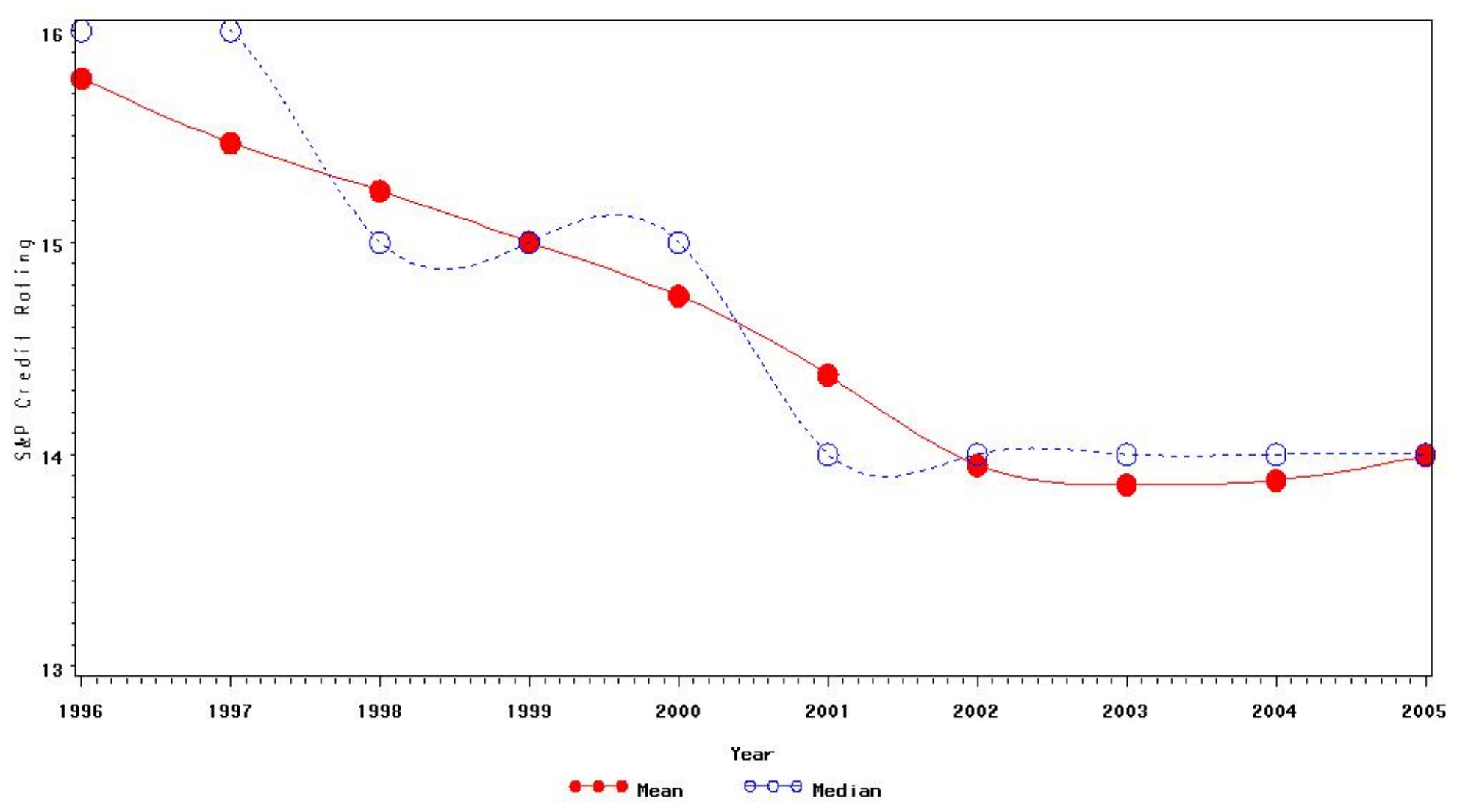




\section{References}

Adams, Renee, and Daniel Ferreira, 2007, A Theory of Friendly Boards, Journal of Finance, Vol. LXII, No. 1, February, 217-250

Adams, Renee, Benjamin Hermalin, and Michael Weisbach, 2008. The Role of Boards of Directors in Corporate Governance: A Conceptual Framework and Survey, NBER Working Paper

Anderson, Ronald, Sattar A. Mansi, and Dvaid M. Reeb, 2004. Board Characteristics, Accounting Report Integrity, and the Cost of Debt. Journal of Accounting and Economics, 37, 315-342.

Andrade, Sandro, Gennaro Bernile, and Frederick Hood, 2008, SOX, Corporate Transparency, and the Cost of Debt, Working Paper, University of Miami

Ashbaugh-Skaife, H., D. Collins, and R. LaFond, 2006. The Effects of Corporate Governance on Firms' Credit Ratings. Journal of Accounting and Economics, 42, 203-243.

Ashbaugh-Skaife, H., D. Collins, and R. LaFond, 2007. Corporate Governance, Risk and Cost of Equity Capital. Working Paper, MIT

Bhojraj, S., and P. Sengupta, 2003. Effects of Corporate Governance on Bond Ratings and Yields: The Role of Institutional Investors and Outside Directors. Journal of Business 76, 455-476.

Blume, Marshall, Felix Lim, and A. Craig Mackinlay, 1998, The Declining Credit Quality of U.S. Corporate Debt: Myth or Reality? Journal of Finance, Vol. LIII, No. 4, 1389-1413

Boone, Andra, Laura Field, Jonathan Karpoff, and Charu Raheja, 2007, The Determinants of Corporate Board Size and Composition: An Empirical Analysis. Journal of Financial Economics, 85, 66-101

Borokhovich, Kenneth, Robert Parrino, and Teresa Trapani, 1996, Outside Directors and CEO Selection, Journal of Financial and Quantitative Analysis, Vol. 31, No. 3, 337-355.

Bradley, Michael., A. Desai and E. Han Kim, 1988. Synergistic Gains from Corporate Acquisitions and Their Division Between Target and Acquiring Firms, Journal of Financial Economics, 21 (May): 3-40.

Bradley, Michael and Dong Chen, 2009, When Does Governance Matter to Bondholders, and How? Work in Progress, University of Baltimore

Bradley, Michael, Dong Chen, George Dallas, and Elizabeth Snyderwine, 2009, The Effects of Corporate Governance Attributes on Credit Ratings and Bond Yields, Working Paper, Duke University

Chava, Sudheer, Martin Dierker, Dmitry Livdan, and Amiyatosh Purnanandam, 2008. Do Shareholder Rights Affect the Cost of Bank Loans? Review of Financial Studies, December, 1-32.

Chhaochharia, Vidhi, and Yaniv Grinstein, 2007, Corporate Governance and Firm Value: The Impact of the 2002 Governance Rules, Journal of Finance, Vol. LXII, No. 4, August, 1789-1825

Chhaochharia, Vidhi, and Yaniv Grinstein, 2009, CEO Compensation and Board Structure, Journal of Finance, Vol. LXIV, No. 1, February, 231-261 
Cremers, Martijn, Vinay B. Nair, and Chengyang Wei, 2007, Governance Mechanisms and Bond Prices, forthcoming, Review of Financial Studies. 1359-1388

Dallas, George and J. Kochetygova, 2007. Standard \& Poor's Corporate Governance Scores and Evaluation Criteria, Methodology, and Definitions. Standard \& Poor's Rating Direct, February.

DeFond, Mark, Mingyi Hung, Emre Karaoglu, and Jieying Zhang, 2008, Was the Sarbanes-Oxley Act Good News for Corporate Bondholders? Working Paper, University of Southern California

Demsetz, Harold and Kenneth Lehn, 1985, The Structure of Corporate Ownership: Causes and Consequences. Journal of Political Economy, 93, 1155-1177

Duchin, Ran, John Matsusaka, and Oguzhan Ozbas, 2009, When Are Outside Directors Effective? Working Paper, University of Southern California

Ertugrul, Mine and Shantaram Hegde, 2008, Board Compensation Practices and Agency Costs of Debt, Journal of Corporate Finance, 14, 512-531

Fama, E., and M. Miller, 1972, The Theory of Finance. Hinsdale, IL: Dryden Press

Fitch Ratings, 2004. Credit policy special report, evaluating corporate governance: the bondholders' perspective, New York.

Graham, John and Campbell Harvey, 2001, The Theory and Practice of Corporate Finance: Evidence From The Field. Journal of Financial Economics, 60, 187-243.

Harris, Milton, and Artur Raviv, 2006, A Theory of Board Control and Size, Review of Financial Studies, forthcoming

Hermalin, Benjamin, and Michael Weisbach, 1998, Endogenously Chosen Boards of Directors and Their Monitoring of the CEO, American Economic Review, Vol. 88, No. 1, 96-118.

Hermalin, Benjamin, and Michael Weisbach, 2003, Boards of Directors as an Endogenously Determined Institution, A Survey of the Economic Literature, FRBNY Economic Policy Review, April, 7-26.

Horrigan, James, 1966, The Determinants of Long-term Credit Standing with Financial Ratios, Journal of Accounting Research, Vol. 4, 44-62

Hovakimian, Armen, Ayla Kayhan, and Sheridan Titman (2008), Credit Rating Targets and Corporate Decisions, Working Paper, Baruch College.

Jensen, Michael and William Meckling, 1976, Theory of the Firm: Managerial Behavior, Agency Costs, and Ownership Structure. Journal of Financial Economics, 3, 305-360

Kaplan, Robert and Gabriel Urwitz, 1979, Statistical Models of Bond Ratings: A Methodological Inquiry. The Journal of Business, Vol. 52, No. 2, 231-261

Klock, Mark, Sattar A. Mansi, and William F. Maxwell, 2005. Does Corporate Governance Matter to Bondholders? Journal of Financial and Quantitative Analysis, vol. 40, no. 4, 693-719 
Larcker, David, S. Richardson, and I. Tuna, 2004. Does Corporate Governance Really Matter? Working paper, Wharton School, University of Pennsylvania.

Linck, James, Jeffry Netter, and Tina Yang, 2008, The Determinants of Board Structure, Journal of Financial

Economics, 87, 308-328

Linck, James S., Jeffry Netter, and Tina Yang, 2009, The Effects and Unintended Consequences of the SarbanesOxley Act on the Supply and Demand for Directors, Review of Financial Studies, Forthcoming

Miller, Jay, 2009. S\&P Puts \$578 Billion Worth of CDO Tranches on Watch for Downgrades. Wall Street Journal, September 17

Morck, Randall, Andrei Shleifer, and Robert Vishny, 1988, Management Ownership and Market Valuation: An Empirical Analysis. Journal of Financial Economics, 20, 293-315.

Myers, Stewart, 1977, Determinants of Corporate Borrowing, Journal of Financial Economics, 5, 147-175

Neyman, J. and Elizabeth Scott, 1948, Consistent Estimates Based on Partially Consistent Observations. Econometrica, Vol. 16, No. 1, 1-32

Petersen, Mitchell, 2008. Estimating Standard Errors in Finance Panel Data Sets: Comparing Approaches. forthcoming, Review of Financial Studies, vol. 22, no. 1, 435-480

Qiu, Jiaping and Fan Yu, 2008. The Market for Corporate Control and the Cost of Debt. forthcoming, Journal of Financial Economics

Raheja, Charu, 2005. Determinants of Board Size and Composition: A Theory of Corporate Boards. Journal of Financial and Quantitative Analysis, vol. 40, no. 2, 283-306

Scannel, Kara, 2009. SEC Looks to Prohibit Flash Trade, Curb Raters. Wall Street Journal, September 17

Standard \& Poor's, 2002. Standard \& Poor's Corporate Governance Scores: Criteria, Methodology and Definitions. McGraw-Hill Companies, Inc., New York.

Weber, Joseph, 2004, Discussion of the Effects of Corporate Governance on Firms' Credit Ratings. Journal of Accounting and Economics, 42, 245-254

Weisbach, Michael, 1988, Outside Directors and CEO Turnover, Journal of Financial Economics, 20, 431-460

Wintoki, Modupe, 2007, Corporate Boards and Regulation: The Effect of the Sarbanes-Oxley Act and the Exchange Listing Requirements on Firm Value, Journal of Corporate Finance, 13, 229-250

Zhang, Jieying, 2007, Economics consequences of the Sarbanes-Oxley Act of 2002. Journal of Accounting and Economics, 44, 74-115 